\title{
PERLINDUNGAN TERHADAP \\ PEMENUHAN NAFKAH ANAK DALAM \\ PELAKSANAAN PUTUSAN \\ PERCERAIAN DI PENGADILAN AGAMA
}

\author{
Rohmad Agus Solihin \\ Fakultas Syariah Institut Agama Islam Negeri (IAIN) Jember, Jember, \\ Jl. Mataram No.1, Karang Miuwo, Mangli, Kec. Kaliwates, Kabupaten Jember, \\ Jawa Timur 68136, Indonesia I rohmadagussolihin@gmail.com \\ DOI: https://doi.org/10.35719/ijl.v1i2.97
}

\begin{abstract}
Parents are the first party responsible for protecting and fulfilling children's rights. The rights of children to parents begin when their children are born and breathe the air in this world. So since then the responsibility of parents to their children has also arisen. Among the rights of children that must be fulfilled by parents is the right to support. Regarding family income, fathers are obliged to provide for their children if they need them, so children are obliged to provide for their mother and father if they need them. If the father is in poverty or his income is insufficient, the obligation to provide for his children remains, does not die, and if the mother of the children is well off, he can be ordered to provide for his children, which is their father's obligation, but can be billed for return it. However, the income that the father (husband) cannot afford can be billed to be returned, the laws which in Indonesia have not regulated that far.
\end{abstract}

Key Words : Protection, Child Livelihoods, Divorce Judgment

Abstrak : Orang tua merupakan pihak pertama yang bertanggung jawab terhadap perlindungan dan pemenuhan hakhak anak. Hak anak pada orang tua dimulai sejak anaknya dilahirkan dan menghirup udara di dunia ini. Maka sejak itu pula timbul tanggung jawab orang tua terhadap anak-anaknya. Diantara hak-hak anak yang harus dipenuhi oleh orang tua adalah hak nafkah. Tentang nafkah keluarga, ayah berkewajiban mencukupkan nafkah anak-anaknya apabila mereka memerlukan, demikia pula anak berkewajiban mencukupkan

\section{IJLIL: INDONESIAN JOURNAL OF LAW AND ISLAMIC LAW VOLUME 2 NOMOR 1 JANUARI-JUNI 2020; \\ ISSN 2721-5261 E-ISSN 2775-460X}


nafkah ibu bapaknya apabila mereka memerlukan. Apabila ayah dalam keadaan fakir atau penghasilannya tidak mencukupi, kewajiban memberi nafkah kepada anak-anaknya itu tetap ada, tidak menjadi gugur, dan apabila ibu anak-anak berkecukupan dapat diperintahkan mencukupkan nafkah anak-anaknya yang menjadi kewajiban ayah mereka itu, tetapi dapat ditagih untuk mengembalikannya. Namun tentang nafkah yang tidak mampu ditunaikan oleh ayah (suami) bisa ditagih untuk dikembalikan, perundang-undangan yang di Indonesia belum mengatur sejauh itu.

Kata Kunci: Perlindungan, Nafkah Anak, Putusan Perceraian

\section{Pendahuluan}

Sengketa perceraian menjadi salah satu sengketa yang sangat mendominasi di Pengadilan Agama. ${ }^{1}$ Perkara perceraian yang mendominasi tersebut disadari memang pada dasarnya dalam permasalah keluarga itu sangat banyak dan beragam dan sangat butuh sekali untuk diselesaikan secara damai (musyawarah mufakat).

Perkawinan merupakan suatu perjanjian yang mengikat lahir batin dengan dasar iman. Hidup bersama merupakan suatu fenomena yang merupakan kodrat bagi setiap manusia, dan mengingat manusia merupakan makhluk sosial, sehingga hanya manusia-manusia yang memiliki permasalahan yang menyendiri dari lingkungannya. Dalam bentuknya yang terkecil, hidup bersama itu dimulai dengan adanya keluarga.

\footnotetext{
1 Lihat Istri Gugat Cerai Dominasi Kasus Pengadilan Agama Bukittinggi. www.replubika.co.id, diakases tanggal 9 Desember 2016.
} 
Lembaga perkarinan merupakan dasar peradaban umat manusia dan tempat bagi manusia untuk mengabadikan diri satu sama lain dan saling menghormati perasaan yang lain. ${ }^{2}$

Pasal 1 Undang-Undang Nomor 1 Tahun 1974 tentang Perkawinan merumuskan pengertian perkawinan sebagai berikut :

Perkawinan adalah ikatan lahir batin antara seorang pria dengan seorang wanita sebagai suami istri dengan tujuan membentuk keluarga (rumah tangga) yang bahagia dan kekal berdasarkan Ketuhanan Yang Maha Esa.

Pasal 2 ayat (1) Undang-Undang Nomor 1 Tahun $1974^{3}$ tentang sahnya perkawinan yang berbunyi :

Perkawinan adalah sah apabila dilakukan menurut

hukum masing-masing agamanya dan kepercayaannya itu.

Usaha perdamaian yang diusahakan oleh salah satu pihak tadi ada yang berhasil dan ada pula yang tidak berhasil tercipta perdamaian. Permasalahan kelurga yang menumpuk tadi kemudian diajukan ke Pengadilan sebagai salah satu pengadilan yang secara formil berwenang untuk menyelesaikan permasalahan perceraian.

Pengadilan dalam proses beracara sengketa perceraian di pengadilan secara formil diharuskan untuk mengusahakan

\footnotetext{
${ }^{2}$ Lili Rasjidi, Hukum Perkawinan dan Perceraian di Malaysia dan di Indonesia, (Bandung: PT Remaja Rosdakarya, 1991), hlm. 1.

3 Terpetin dari UU No. 1 Tahun 1974 tentang Perkawinan..
} 
melaksanakan mediasi yang dibantu oleh seorang mediatoir. Baik cerai talak dan cerai gugat, para pihak yang kesemuanya hadir tersebut diharuskan untuk melaksankan mediasi sebagai upaya proses damai di Pengadilan. ${ }^{4}$ Bilamana mediasi berhasil dilaksanakan maka proses perceraian dihentikan dengan mencabut surat gugatan dan diterbitkannya Akta Perdamaian. Sedangkan bilamana mediasi gagal atau tidak berhasil maka proses persidangan berlanjut ke sidang pokok perkara.

Sidang pokok perkara yang dilaksanakan peradilan tentunya sesuai dengan hukum acara perdata yang berlaku di pengadilan. Sering kali proses persidangan menjadi lama, karena salah satu pihak itu tidak berkenan dengan adanya perceraian tersebut. Namun adakalanya juga proses persidangan menjadi sangat cepat karenan para pihak sudah sepakat pisah baik-baik.

Perceraian terbagi menjadi 2 (dua) yakni sengketa cerai talak dan cerai gugat. Cerai talak yakni suatu perkara perceraian yang pengajuan diajukan oleh pihak suami, agar pengadilan memberikan hak untuk mengucapkan ikrar cerai kepada Istri. Sedangkan cerai gugat yaitu suatu proses perceraian yang pengajuan dilakukan oleh pihak istri akibat adanya ketidaharmonisan antara suami istri tersebut, dan

\footnotetext{
${ }^{4}$ Lihat Pasal 4 Peraturan Mahkamah Agung Nomor 1 Tahun 2016 tentang Prosedur Mediasi di Pengadilan.
} 
memohon kepada pengadilan agar memutuskan perceraian antara pihak suami dan istri.

Secara umum alasan perceraian dalam masyarakat adalah sudah tidak ada lagi kecocokan di antara suami dan istri yang disebabkan oleh berbagai hal. Perceraian merupakan suatu perbuatan hukum yang tentunya akan membawa pula akibatakibat hukum tertentu. Sesuai dengan ketentuan Pasal 144 Kompilasi Hukum Islam (KHI), perceraian dapat terjadi karena adanya talak dari suami atau gugatan perceraian yang dilakukan oleh istri, perceraian tersebut hanya dapat dilakukan atas dasar putusan hakim di depan sidang Pengadilan Agama (Pasal 115 KHI).

Perceraian yang terjadi karena adanya talak dari suami terhadap istrinya, maka sesuai dengan ketentuan Pasal 41 (c) Undang-Undang Nomor 1 Tahun 1974, pengadilan dapat mewajibkan kepada mantan suami untuk memberikan biaya penghidupan dan atau menentukan sesuatu kewajiban kepada mantan istrinya. Pasal ini menetukan kewajiban dari mantan suami yang berupa mut'ah, nafkah iddah (bila istrinya tidak nusyus) dan nafkah untuk anak-anak. Dalam hal ini walaupun tidak adanya suatu tuntutan dari istri majelis hakim dapat menghukum mantan suami membayar kepada mantan istri berupa mut'ah, nafkah iddah dan nafkah anak.

Tentunya perkara cerai talak dan cerai gugat mempunyai akibat masing-masing akibat dua perceraian tersebut. Yang 
pada umumnya perceraian akan menyangkut mengenai hak asuh anak, harta gono-gini dan juga nafkah anak pasca perceraian. Perceraian yang terjadi antara suami istri yang menjadi korban adalah anak-anaknya. Memang pihak suami istri menyadari bahwa anak itu tidak ada suratnya (tidak ada putusnya), namun secara praktik setelah ikrar talak diucapkan kemudian para pihak menikah baru dengan pasangan yang baru mereka mempunyai keluarga yang baru.

Perkara perceraian yang terjadi berdampak pada hak nafkah anak yang tidak dapatkan semestinya. Karena sering kali terjadi nafkah tidak diberikan bagi pihak suami kepada anaknya dari mantan istri dengan bermacam problematika dan alasan. Terlebih suami diharuskan untuk membiayai keluarga barunya. Hal tersebut berdampak terhadap kehidupan anaknya yang tidak memperoleh hak nafkah yang seharusnya dari si ayah yang mempunyai keluarga baru, dan lebih mementingkan keluarga barunya.

Penting untuk dipahami bahwa anak tersebut mempunyai hak yang sepenuhnya dari orang tua, meskipun orang tuanya tersebut telah berpisah. Praktik di masyarakat pasca perceraian terjadi, anak-anak hasil perceraian tidak mendapatkan selayaknya. Menjadi permasalahan tersendiri bagaimana produk hukum dapat mengcover dan melindungi hak nafkah anak setelah perceraian. 
Pasal 34 ayat (1) UU No. 1 Tahun 1974 tentang Perkawinan menyatakan,suami wajib melindungi istrinya dan memberikan segala sesuatu keperluan hidup berumah tangga sesuai dengan kemampuannya. Ini kalau Anda memegang konsep suami sebagai kepala keluarga. Kalau konsepnya istri yang menjadi kepala keluarga, atau keduanya bersama-sama sudah mengatur konsep lain, tentu lain ceritanya. ${ }^{5}$

Pasal 34 Undang-Undang Perkawinan No. 1 Tahun 1974 menyatakan sebagai berikut:

a. Suami wajib melindung istrinya dan memberikan segala sesuatu keperluan hidup berumah tangga sesuai dengan kemampuannya.

b. Istri wajib mengatur urusan rumah tangga sebaikbaiknya.

c. Jika suami atau istri melalaikan kewajibanya masingmasing dapat mengajukan gugatan kepada Pengadilan.

Cobaan yang datang setelah pernikahan merupakan ujian yang harus dihadapi dengan kematangan sikap dan kematangan berpikir. Idealnya harus dihadapi dengan hati dan pikiran yang terbuka, selalu berprasangka positif, serta dengan adanya komunikasi yang baik. Semuanya menjadi kunci utama dalam sebuah kebahagiaan, yang akan membebaskan pasangan dari rasa curiga, pikiran negatif, dan kecemasan lainnya. Komunikasi merupakan jembatan

5 Terpetik dari Kejarlah Nafkah Sampai Ke Pengadilan, www.hukumonline.com, diakses pada tanggal 9 Desember 2016. 
pembentuk kepercayaan. Dengan komunikasi pasangan lebih bisa menentukan langkah ke depan menuju kebahagiaan yang diinginkan.

Tentunya, ketika islam yang menyatukan, maka islam pula yang memisahkan ketika jalan perpisahan menjadi jalan yang tepat dalam menyelesaikan permasalahan yang terjadi dalam pernikahan. Perceraian ada karena perkawinan, tidak ada perkawinan tentu tidak ada perceraian. Karena itu perkawinan awal hidup bersama sebagai suami istri dan perceraian akhir hidup bersama suami istri.

Perceraian adalah sesuatu yang dibolehkan dalam ajaran Islam apabila sudah ditempuh berbagai cara untuk mewujudkan kerukunan, kedamaian, dan kebahagiaan, namun harapan dalam tujuan perkawinantidak akan terwujud atau tercapai sehingga yang terjadi adalah perceraian. Perceraian diatur dalam Undang-Undang Nomor 7 Tahun 1989 (selanjutnya disebut UUPA) dan Pasal 115 KHI.

Menurut UU No. 1 Tahun 1974 walaupun orang tua sudah bercerai, mereka masih terikat pada kewajiban untuk memelihara anak-anak yang telah lahir dari perkawinan mereka. Juga dapat diketahui bahwa baik ibu ataupun bapak mempunyai hak yang sama terhadap pemeliharaan anak.

Dalam hal ini dengan siapapun anak ikut, ayah sebagai mantan suami tetap berkewajiban memberikan nafkah 
kepada anak untuk biaya hidup dan pendidikannya sampai anak menjadi dewasa atau anak tersebut telah kawin. Namun demikian ibu juga dapat ditetapkan untuk ikut memikul beban biaya pemeliharaan anak tersebut.

Dalam prakteknya kadang terjadi bahwa terhadap putusan penetapan biaya pemeliharaan anak yang dibebankan kepada ayah ternyata tidak dipatuhi mantan suami, sehingga ibu yang memelihara anak menjadi kesulitan dalam menghidupi dan memelihara anaknya. Dalam keadaan demikian ibu dapat mengajukan gugatan pemenuhan kewajiban pemberian biaya pemeliharaan anak tersebut ke Pengadilan, dan selanjutnya menunggu keputusan Hakim terhadap permohonan tersebut.

Suami setelah putusnya peceraian oleh Pengadilan Agama, suami tidak memperhatikan hak-hak anak seperti nafkah anak dan juga biaya pendidikan yang pada dasarnya masih menjadi hak anak dari ayahnya. ${ }^{6}$ Banyaknya permasalahan nafkah anak yang tidak diberikan itu mendasar pemikiran penulis dalam tulisan kali ini. Peneliti ingin meneliti tentang kewajiban hukum hak nafkah anak terhadap sengketa cerai talak oleh suami. Sehingga menjadikan putusan pengadilan dapat melindungi nafkah anak yang diberikan oleh sumai kepada anak pasca perceraian di pengadilan. Pengadilan yang merupakan salah satu bentuk

\footnotetext{
6 Lihat Hak-Hak Istri Dalam Proses Perceraian, http://www.pakarawang.go.id/artikel/baca/21, diakses pada tanggal 9 Desember 2016.
} 
terwujudnya keadilan yang bermartabat, berwibawa dalam rangka Negara Hukum Republik Indonesia.

\section{Pembahasan}

\section{Pengertian Perkawinan}

Perkawinan merupakan suatu kejadian yang sangat penting dalam kehidupan seseorang. Bagi bangsa Indonesia ritual perkawinan tidak hanya dipandang sebagai peristiwa sosial keduniawian, melainkan juga dipandang sebagai peristiwa sakral. Setelah selesai ritual, timbullah ikatan perkawinan antara seorang laki-laki dan seorang wanita yang menimbulkan akibat dalam berbagai bidang, meliputi hubungan lahiriah dan spiritual di antara mereka (suamiisteri) itu sendiri secara pribadi dan kemasyarakatan, serta hubungan antara mereka dengan harta kekayaan yang diperoleh sebelum selama, dan sesudah perkawinan.

Seorang laki-laki dan seorang wanita yang dulunya merupakan pribadi yang bebas tanpa ikatan hukum, setelah perkawinan menjadi terikat lahir dan batin sebagai suami isteri. Ikatan yang ada di antara mereka adalah ikatan lahiriah, rohaniah-spiritual dan kemanusiaan. Ikatan perkawinan ini menimbulkan akibat hukum terhadap diri masing-masing suami isteri, maupun akibat berupa hubungan hukum di antara suami isteri yang berupa hak dan kewajiban. 
Apabila dalam perkawinan tersebut dilahirkan seorang anak, maka anak tersebut mempunyai kedudukan sebagai anak sah. Selanjutnya ikatan perkawinan antara seorang pria dengan seorang wanita juga mempunyai pengaruh terhadap masyarakat sekitarnya.

Pasal 1 Undang-Undang Nomor 1 Tahun 1974 tentang Perkawinan menjelaskan bahwa Perkawinan ialah ikatan lahir batin antara seorang pria dewasa dengan seorang wanita sebagai suami istri dengan tujuan membentuk keluarga (rumah tangga) yang bahagia dan kekal berdasarkan Ketuhanan Yang Maha Esa.

Menurut Undang-Undang Perkawinan barulah ada perkawinan apabila dilakukan antara seorang pria dan seorang wanita, berarti perkawinan sama dengan perikatan. Tentulah tidak dinamakan perkawinan apabila yang terikat dalam perjanjian itu 2 (dua) orang pria saja ataupun 2 (dua) orang wanita saja. Demikian juga tidaklah merupakan perkawinan bila dilakukan antara banyak pria dan banyak wanita.7

Tentulah juga mungkin tidak merupakan perkawinan kalau sekiranya ikatan lahir batin itu tidak bahagia, atau perkawinan itu tidak kekal dan tidak berdasarkan Ketuhanan Yang Maha Esa. Perjanjian dalam perkawinan mempunyai

7 Hilman Hadikusumo, Hukum Perkawinan Indonesia, (Bandung: Mandar Maju, 1990), hlm. 7 . 
atau mengandung 3 (tiga) karakter yang khusus, yaitu :8

a. Perkawinan tidak dapat dilakukan tanpa unsur suka rela dari kedua belah pihak.

b. Kedua belah pihak (laki-laki dan perempuan) yang mengikat persetujuan perkawinan itu saling mempunyai hak untuk memutuskan perjanjian tersebut berdasarkan ketentuan yang sudah ada hukum-hukumnya.

c. Persetujuan perkawinan itu mengatur batas-batas hukum mengenai hak dan kewajiban masing-masing pihak.

Persetujuan perkawinan itu pada dasarnya tidaklah sama dengan persetujuan-persetujuan yang lainnya, misalnya persetujuan jual beli, sewa-menyewa, tukar menukar. Perbedaan antara persetujuan perkawinan dan persetujuanpersetujuan yang lainnya adalah :

"Dalam persetujuan biasa para pihak pada pokoknya. Penuh merdeka untuk menentukan isi dari persetujuan itu sesuka hatinya, dengan ketentuan bahwa persetujuan itu tidak bertentangan dengan Undang-Undang kesusilaan dan ketertiban umum. Sebaliknya dalam suatu perkawinan sudah sejak semula ditentukan oleh hukum, isi dari persetujuan antara suami istri itu"

\footnotetext{
${ }^{8}$ Mohammad Idris Ramulyo, Hukum Perkawinan Islam, (Jakarta: Bumi Aksara, 1999), hlm. 15 .
} 
Menurut Undang-Undang Perkawinan asas yang dianut adalah asas monogami yang secara otentik diatur di dalam Pasal 3 ayat (1) yang berbunyi sebagai berikut :

Pada asasnya dalam suatu perkawinan seorang pria hanya boleh mempunyai seorang istri, seorang wanita hanya boleh mempunyai seorang suami. Kaidah Pasal 3 ayat (1) tersebut terdapat kemiripan dengan bunyi Pasal 27 Kitab UndangUndang Hukum Perdata yang menyatakan bahwa:

Dalam waktu yang sama seorang laki-laki hanya diperbolehkan mempunyai satu orang perempuan sebagai istrinya, seorang perempuan hanya satu orang laki-laki sebagai suaminya.Perbedaannya terletak pada Pasal 3 ayat (2) Undang-Undang Perkawinan yang menyatakan bahwa :

Pengadilan dapat memberi ijin kepada seorang suami untuk beristri lebih dari seorang apabila dikehendaki oleh pihak-pihak yang bersangkutan. Dengan adanya pasal tersebut berarti Undang-Undang Nomor 1 Tahun 1974 tentang Perkawinan menganut Asas Monogami terbuka, sebab tidak tidak tertutup kemungkinan dalam keadaan terpaksa suami melakukan poligami. Sebagaimana diatur dalam Pasal 3 ayat (2) Undang-Undang Perkawinan yang menyatakan di dalam penyelarasannya bahwa pengadilan dalam memberikan putusan selain memeriksa apakah syarat yang tersebut dalam Pasal 4 dan Pasal 5 telah dipenuhi. Bunyi kedua pasal tersebut 
adalah sebagai berikut :

Pasal 4 Undang-Undang Nomor 1 Tahun 1974 yakni :

(1) Dalam hal seorang suami akan beristri lebih dari seorang sebagaimana tersebut dalam Pasal 3 ayat (2) Undang-Undang ini, maka diwajib mengajukan permohonan kepada pengadilan di daerah tempat tinggalnya.

(2) Pengadilan dimaksud dalam ayat (1) pasal ini hanya memberikan ijin kepada suami yang beristri lebih dari seorang apabila :

a. Istri tidak dapat menjalankan kewajibannya sebagai istri.

b. Istri mendapat cacat badan atau penyakit yang tidak dapat disembuhkan.

c. Istri tidak dapat melahirkan keturunan.

Pasal 5 Undang-Undang Nomor 1 Tahun 1974, berbunyi:

(1) Untuk dapat mengajukan permohonan kepada pengadilan sebagaimana dimaksud dalam Pasal 4 ayat (1) Undang-Undang ini, harus dipenuhi syaratsyarat sebagai berikut :

a. Adanya persetujuan dari istri

b. Adanya kepastian bahwa suami menjamin keperluan-keperluan hidup istri-istri dan anakanak mereka. 
c. Adanya jaminan bahwa suami akan berlaku adil terhadap istri-istri dan anak-anak mereka.

(2) Persetujuan yang dimaksud pada ayat (1) menurut pasal ini tidak diperlukan bagi seorang suami apabila istrinya/istri-istrinya tidak mungkin dimintai persetujuannya dan tidak dapat menjadi pihak dalam perjanjian, atau apabila tidak ada cacat dari istrinya selama sekurang-kurangnya 2 (dua) tahun, atau karena sebab-sebab lainnya yang perlu mendapat penilaian dari hakim pengadilan.

Dengan adanya akad nikah, maka bagi suami istri timbul hak dan kewajiban diantara keduanya. Hak dan kewajiban itu adalah:

1) Suami wajib menegakkan rumah tangga yang merupakan sendi masyarakat.

2) Hak dan kedudukan suami istri adalah seimbang, masing-masing berhak melakukan perbuatan hukum. Suami adalah kepala keluarga dan istri adalah ibu rumah tangga.

3) Suami istri harus mempunyai tempat kediaman yang tetap dan bersama-sama.

4) Suami istri wajib saling mencintai, saling menghormati, setia dan memberi bantuan lahir batin satu sama lain.

5) Suami wajib melindungi istri dan memberikan keperluan hidup berumah tangga sesuai dengan 
kemampuannya dan istri wajib

Beberapa ketentuan dalam Al-Qur'an yang menunjukkan hak dan kewajiban suami istri itu adalah :9

Al-Qur'an Surat Annisa' ayat 19 yang artinya : "Dan bergaullah kamu dengan istri kamu dengan makruf'. Katakata makruf di sini berarti menunjukkan iktikat baik, baik mengenai hubungan orang dengan orang, maupun mengenai hubungan orang dengan orang yang di dalamnya tersangkut harta kekayaan.

Qur'an Surat Annisa' ayat 4 artinya : "Wanita yang saleh ialah yang taat kepada Allah dan memelihara diri". Memelihara diri di sini berarti memelihara rumah tangganya, memelihara rahasia suaminya serta rahasia keluarganya.

Juga dalam Surat Arrum ayat 21 yang artinya : "Dan dari pertanda Tuhan menjadikan antara suami istri itu mawaddah cinta menyintai dan ramah santun menyantuni”. Sedangkan mengenai tanggung jawab suami sebagai kepala keluarga terdapat di dalam Qur'an Surat Annisa' ayat 34.

\section{Akibat Perkawinan yang Sah}

Perkawinan yang sah menurut hukum akan menimbulkan akibat hukum sebagai berikut : ${ }^{10}$

a. Timbulnya hubungan antara suami-istri

\footnotetext{
9 Sofyan Hasan, Dasar-Dasar Memahami Hukum Islam di Indonesia, (Surabaya: Usahan Nasional, 1994), hlm. 118.

10 Mulyadi, Hukum Perkawinan Indonesia, (Semarang: Badan Penerbit Universitas Diponegoro, 2008), hlm. 41.
} 
b. Timbulnya harta benda dalam perkawinan

c. Timbulnyan hubungan antara orang tua dan anak. ${ }^{15}$

Akibat perkawinan terhadap suami isteri menimbulkan hak dan kewajiban antara suami isteri. Lebih lanjut Pasal 30 sampai dengan Pasal 34 Undang-Undang Nomor 1 Tahun 1974 tentang Perkawinan mengatur hak dan kewajiban antara suami isteri, sebagai suatu konsekuensi dari perkawinan, yaitu sebagai berikut:

a. Suami isteri memikul kewajiban yang luhur untuk menegakkan rumah tangga yang menjadi sendi dasar susunan masyarakat;

b. Hak dan kedudukan isteri adalah seimbang dengan hak dan kedudukan suami dalam kehidupan rumah tangga dan dalam pergaulan masyarakat;

c. Suami-isteri berhak melakukan perbuatan hukum;

d. Suami adalah kepala rumah tangga dan isteri ibu rumah tangga. Disamping itu suami wajib memberikan segala sesuatu keperluan hidup berumah tangga dengan kemampuannya dan isteri wajib mengatur rumah tangga sebaik-baiknya;

e. Suami isteri wajib saling mencintai, hormat menghormati, setia dan memberi bantuan lahir batin satu kepada yang lain;

f. Suami isteri harus mempunyai tempat kediaman yang tetap dan tempat kediaman tesebut ditentukan oleh 
suami isteri bersama.

Selanjutnya apabila suami atau isteri melalaikan kewajiban, maka masing-masing dapat mengajukan gugatan kepada Pengadilan. Sedangkan akibat perkawinan yang menyangkut harta benda dalam perkawinan, diatur dalam Pasal 35 sampai Pasal 37 UU No. 1 Tahun 1974, yang menetapkan sebagai berikut :

Harta benda yang diperoleh selama perkawinan menjadi harta bersama, sedangkan harta bawaan dari masing-masing suami atau isteri dan harta benda yang diperoleh masingmasing sebagai hadiah atau warisan, adalah di bawah penguasaan masing-masing, sepanjang tidak ditentukan lain oleh suami-isteri. Apabila ditentukan oleh suami isteri, maka harta bawaan suami isteri tersebut menjadi harta bersama. Untuk menentukan agar harta bawaan suami dan isteri menjadi harta bersama, maka suami dan isteri tersebut harus membuat perjanjian kawin. Perjanjian kawin harus dibuat secara tertulis dan disahkan oleh Pegawai Pencatat Perkawinan sebelum atau pada saat perkawinan dilangsungkan;

Perjanjian kawin adalah perjanjian perjanjian yang dibuat calon suami dan isteri untuk mengatur akibat-akibat perkawinannya terhadap harta kekayaan mereka. Perjanjian kawin diatur dalam Pasal 29 UU No. 1 Tahun 1974, yang 
menetapkan :

a. Pada waktu atau sebelum perkawinan dilangsungkan, kedua pihak atas persetujuan bersama dapat mengadakan perjanjian kawin yang disahkan oleh Pegawai Pencatat Perkawinan, setelah mana isinya berlaku juga terhadap pihak ketiga sepanjang pihak ketiga tersangkut.

b. Perjanjian tersebut tidak dapat disahkan bilamana melanggar batas-batas hukum agama dan kesusilaan.

c. Perjanjian tersebut berlaku sejak perkawinan dilangsungkan

d. Selama perkawinan berlangsung perjanjian tersebut tidak dapat dirubah, kecuali bila dari kedua belah pihak ada persetujuan untuk merubah dan Perubahan tidak merugikan pihak ketiga.

e. Mengenai harta bersama, suami atau isteri dapat bertindak bertindak atas persetujuan kedua belah pihak. Sedangkan mengenai harta bawaan masing-masing, suami isteri mempunyai hak sepenuhnya untuk melakukan perbuatan hukum hak sepenuhnya untuk melakukan perbuatan hukum mengenai harta bendanya. Adapun hak suami dan isteri untuk mempergunakan atau memakai harta bersama dengan persetujuan kedua belah pihak secara timbal balik, menurut Riduan Syahrani adalah sewajarnya, mengingat hak dan kedudukan suami dalam kehidupan rumah tangga dan pergaulan hidup bersama dalam masyarakat, dimana 
masing-masing pihak berhak melakukan perbuatan hukum. ${ }^{11}$

f. Bila perkawinan putus karena perceraian, harta bersama diatur menurut hukumnya masing-masing. Menurut penjelasan Pasal 37 UU No. 1 tahun 1974, yaitu hukum agama (kaidah agama), hukum adat dan hukum-hukum lainnya.

Akibat perkawinan terhadap anak yang lahir dalam perkawinan, menimbulkan hak dan kewajiban antara orang tua dan anak secara timbal balik.

1) Keadaan orang tua wajib memelihara dan mendidik anakanak sebaik-baiknya, sampai anak itu kawin atau kawin atau dapat berdiri sendirindiri. Selanjutnya kewajiban itu berlaku terus meskipun perkawinan kedua orang tua putus;

2) Dalam praktek, apabila perkawinan putus karena perceraian atau karena atas putusan Pengadilan, maka atas permohonan dari pihak suami atau isteri, Pengadilan akan menyerahkan anak-anak tersebut kepada suami atau isteri yang benar-benar beriktikad baik, untuk dipelihara dan dididik secara baik;Anak yang belum mencapai umur 18 tahun atau belum pernah kawin, berada di bawah kekuasaan orang tuanya, selama mereka tidak dicabut dari

${ }^{" 1}$ Riduan Syahrani, Seluk Beluk dan Asas-Asas Hukum Perdata, (Bandung: Alumni, 1985), hlm. 100. 
kekuasaannya;

3) Orang tua mewakili anak tersebut, mengenai segala perbuatan hukum baik di dalam dan di luar Pengadilan;

4) Orang tua tidak boleh memindahkan hak atau menggadaikan barang-barang yang dimiliki oleh anaknya yang belum berumur 18 tahun belum pernah kawin sebelumnya, kecuali kalau untuk kepentingan anak tersebut yang menghendaki.

5) Kekuasaan salah seorang atau kedua orang tua dapat dicabut kekuasaannya terhadap seorang anak atau lebih, untuk waktu tertentu atas permintaan orang lain, keluarga anak dalam garis lurus ke atas dan saudara kandung yang telah dewasa atau pejabat yang berwenang. ${ }^{12}$

\section{Pelaksanaan Putusan Pengadilan}

Pelaksanaan peradilan di dunia selalu menghasilkan sesuatu yang bernama putusan. Putusan ini menjadi pegangan oleh setiap subjek hukum untuk dapat melaksanakan putusan peradilan tersebut. Hakim dalam memutuskan sutau putusan harus berpegangan terhadap peraturan perundang-undangan dan pancasila. Pasal 2 Undang-Undang Nomor 12 Tahun 2011 disebutkan bahwa Pancasila adalah sumber dari segala sumber hukum negara Indonesia. Hal ini sekiranya dirasa sesuai mengungat bahwa falsafah Pancasila adalah merupakan perjuangan, merupakan

${ }_{12}$ Mulyadi, op.cit, hlm. 45 . 
alat pemersatu dengan mengingat masyarakat Indonesia yang heterogen. Pancasila merupakan pandangan hidup bangsa Indonesia, merupakan jiwa dan kepribadian bangsa Indonesia.

Pada asas semua putusan pengadilan harus memuat alasan-alasannya putusan yang dijadikan dasar untuk mengadili (Pasal 23 UUNo. 14 Tahun 1970), Pasal 184 Ayat (1), Pasal 319 H.I.R., 195 dan 618 R.Bg.). sebagaimana maksud Pasal 28 Ayat (1) UU No. 4 Tahun 2004 yang menyatakan bahwa: "Hakim wajib menggali, mengikuti dan memahami nilai-nilai hukum yang hidup dalam masyarakat". Selain itu dalam mencari dan menemukan hukum berlaku asas ius curia novit, yang berarti, hakim dianggap tahu akan hukumnya.

JJ. H. Bruggink sebagaimana diterjemahkan oleh B. Arief Sidharta dalam Refleksi Tentang Hukum, menjelaskan bahwa:

Dalam proses penemuan hukum, adalah tugas hakim untuk misalnya menilai apakah-fakta dari kejadian tertentu termasuk dalam penegrtian "perbuatan melanggar hukum". dalam Teori Penemuan Hukum dewasa ini Model Hermeneutikal dipandang sebagai pemaparan proses ini yang paling baik. Dalam model ini diperlihatkan bahwa hakim dalam proses penemua hukum berpikir dalam suatu lingkran. Ia menalar dari fakta-fakta dari kejadian ke kaidah dalam aturan hukum (ia mengkualifikasi), untuk kemudian dari 
kaidah dalam aturan hukum itu ke fakta-fakta dari kejadian tersebut (ia menginterpretasi), dan hal itu terjadi berulangulang sampai ia menemukan sebuah penyelesaian.

Herowati Poesoko menjelaskan bahwa hakim dalam memutuskan perkara diwajibkan untuk menafsirkan undangundang sehingga dimungkinkan hakim menemukan hukum dan bahkan menciptakan hukum sebagimana yang terdapat dalam yurisprudensi. Alasan-alasan atau argumentasi itu dimaksudkan sebagai pertangung-jawab hakim dari pada putusannya terhadap masyarakat.kadean adanya alasanalasan itulah maka putusan mempunyai wibawa dan bukan karena hakim tertentu yang menjatuhkannya. ${ }^{13}$ Putusan hakim diharapkan dapat memberi rasa keadilan bagi masyarakat pencari keadilan. Meskipun bilamana putusan suatu peradilan masih dipandang kurang adil dapat mengajukan gugatan ke peradilan diatasnya.

Putusan yang sudah mempunya kekuatan hukum, maka harus dilaksanakan dengan sebaik-baiknya sebagai wujud dari tujuan hukum yakni memberi kepastian hukum.

Penegakan hukum menjadi hal terpenting dalam konsekuensi logis adanya konsep negara hukum, yang dianut dalam UUD NRI Tahun 1945 Pasal 1 Ayat (3). ${ }^{14}$ J.B.J.M. te

${ }_{13}$ Herowati Poesoko, Parate Executie Obyek Hak Tanggungan (Inkonsistensi, Konflik Norma dan Kesesatan Penalaran dalam UUHT), (Yogyakarta: LaksBang PRESSindo Yogyakarta, 2008), hlm. 122.

${ }^{14}$ Lihat UUD NRI Tahun 1945 Pasal 1 Ayat (3) yang menyatakan: Negara Indonesia adalah negara hukum. 
Berge $^{15}$ menguraikan instrument penegakan hukum adminstrasi meliputi : 1) pengawasan; 2) penegakan sanksi. Pelaksanaan putusan (Eksekusi) di atur dalam Pasal 195 HIR, Pasal 195 (1) menyebutkan pelaksanaan pengadilan dari putusan- putusan perkara yang dalam tingkat pertama diperiksa oleh Pengadilan Negeri dijalankan atas perintah dan pimpinan dari Ketua Pengadilan Negeri yang memeriksa perkara itu dalam tingkat pertama dengan cara-yang akan disebutkan dalam ayat berikutnya. ${ }^{16}$

Sudikno Mertokusumo ${ }^{17}$ berpendapat bahwa: Eksekusi adalah realisasi dari kewajiban pihak yang kalah untuk memenuhi prestasi yang tercantum dalam putusan tersebut. Berkaitan dengan pengertian eksekusi yang semakin berkembang dan dirasa semakin penting. Hak seseorang yang dijamin oleh hukum materiil maupun yang sudah dengan tegas dikuatkan oleh pengadilan, tidak ada artinya jika tidak direalisasikan. Di sinilah diperlukan prosedur khusus yang diartikan sebagai proses penyelesaian perkara langsung pada pelaksanaan eksekusi, tidak perlu dilakukan melalui pengajuan gugatan pada pengadilan. Istilah eksekusi di sini diartikan sebagai realisasi hak kreditor secara paksa dilakukan

\footnotetext{
15 J.B.J.M. Ten Berge, Recent Developments in General Administrative Law in The Netherlands, (Utrecht: Course Book 1994), p. 21.

${ }^{16}$ Lihat Mochammad Dja'is, Membaca dan Mengerti HIR, (Semarang: Badan Penerbit UNDIP, 2008), hlm. 220.

${ }_{17}$ Sudikno Mertokusumo, Hukum Acara Perdata Indonesia, (Yogyakarta: Liberty, 1995), hlm. 212.
} 
terhadap debitor yang tidak mau secara sukarela melaksanakan kewajibannya.

\section{Hak Nafkah Anak}

Nafkah adalah semua kebutuhan dan keperluan yang berlaku menurut keadaan dan tempat, seperti makanan, pakaian, rumah dan lain-lain. ${ }^{18}$ Tentang nafkah, Hamid Sarong berpendapat bahwa hubungan perkawinan menimbulkan kewajiban nafkah atas suami untuk isteri dan anak-anaknya. Ayah berkewajiban mencukupkan nafkah anak-anaknya apabila mereka memerlukan, demikian pula anak berkewajiban mencukupkan nafkah ibu bapaknya apabila mereka memerlukan, tanpa memperhatikan agama yang dianutnya apakah sama atau berlainan. Kecuali itu didapat juga ketentuan bahwa setiap kerabat yang mempunyai hak waris dari kerabat lain berkewajiban memberi nafkah apabila memerlukan. Menurutnya juga, kewajiban ayah memberikan nafkah kepada anak-anaknya memerlukan syarat-syaratnya sebagai berikut:

a. Anak-anak membutuhkan nafkah (fakir) dan tidak mampu bekerja. Anak dipandang tidak mampu bekerja apabila masih kanak-kanak atau telah besar tetapi tidak mendapatkan pekerjaan atau perempuan.

b. Ayah memiliki kemampuan dalam harta dan mampu untuk memberi nafkah, baik karena memang mempunyai

\footnotetext{
${ }^{18}$ Hamid Sarong, Hukum Perkawinan di Indonesia, (Banda Aceh: PeNa), hlm. 178-182.
} 
pekerjaan yang menghasilkan ataumemiliki kekayaan yang menjadi penompang hidupnya.

Atas dasar adanya syarat-syarat tersebut, apabila anak yang fakir telah sampai pada umur mampu bekerja, meskipun belum baligh, dan tidak ada halangan apapun untuk bekerja, maka gugurlah kewajiban ayah untuk memberi nafkah kepada anak. Berbeda halnya apabila anak telah mencapai umur dapat bekerja itu terhalang untuk bekerja disebabkan sakit atau kelemahan-kelemahan lain, maka ayah tetap berkewajiban memberikan nafkah untuk anaknya itu.

Bagi anak perempuan, kewajiban ayah memberi nafkah kepadanya berlangsung sampai ia kawin, kecuali apabila anak telah mempunyai pekerjaan yang dapat menjadi penompang hidupnya, tetapi tidak dapat dipaksa untuk bekerja mencari nafkah sendiri. Apabila ia telah kawin, maka nafkahnya menjadi kewajiban suami dan apabila suaminya meninggal juga tidak mendapat warisan yang cukup untuk nafkah hidupnya, maka ayahnya berkewajiban lagi memberi nafkah kepadanya seperti pada waktu sebelum menikah.

\section{Kesimpulan}

Adanya hubungan nasab antara orang tua dan ank akan berakibat timbulnya hak dan kewajiban antar orang tua dan 
anak. Hamid Sarong menerankan dalam karyanya Hukum Perkawinan Islam di Indonesia, tentang nafkah keluarga mengatakan bahwa hubungan perkawinan menimbulkan kewajiban nafkah atas suami isteri dan anak-anaknya. Ayah berkewajiban mencukupkan nafkah ibu bapaknya apabila mereka memerlukan, tidak memperhatikan agama yang dianutnya apakah sama atau berlainan. Apabila ayah dalam keadaan fakir atau penghasilannya tidak mencukupi, kewajiban memberi nafkah anak-anaknya itu tetap ada, tidak menjadi gugur, dan apabila ibu anak-anak berkecukupan dapat diperintahkan mencukupkan nafkah anak-anaknya yang menjadi kewajiban ayah mereka, tetapi dapat ditagih untuk mengembalikannya. Apabila ibu fakir juga, maka nafkah yang diberikan kepada cucunya itu kepada ayah. Apabila ayah tidak ada lagi, maka nafkah itu dibebankan kepada kakek, sebab kakek berkedudukan sebagai pengganti ayah dalam hal ayah tidak ada lagi.

\section{Daftar Pustaka}

Hamid Sarong, Hukum Perkawinan di Indonesia, (Banda Aceh: PeNa, $\mathrm{tt}$ )

Herowati Poesoko, Parate Executie Obyek Hak Tanggungan (Inkonsistensi, Konflik Norma dan Kesesatan Penalaran dalam UUHT), (Yogyakarta: LaksBang PRESSindo Yogyakarta, 2008

Hilman Hadikusumo. Hukum Perkawinan Indonesia, (Bandung: Mandar Maju, 1990) 
J.B.J.M. Ten Berge, Recent Developments in General Administrative Law in The Netherlands, (Utrecht: Course Book 1994)

Lili Rasjidi, Hukum Perkawinan dan Perceraian di Malaysia dan di Indonesia, (Bandung: PT Remaja Rosdakarya, 1991)

Mochammad Dja'is. Membaca dan Mengerti HIR. (Semarang: Badan Penerbit UNDIP, 2008)

Mohammad Idris Ramulyo. Hukum Perkawinan Islam. (Jakarta: Bumi Aksara, 1999),

Mulyadi. Hukum Perkawinan Indonesia. (Semarang: Badan Penerbit Universitas Diponegoro, 2008)

Pasal 4 Peraturan Mahkamah Agung Nomor 1 Tahun 2016 tentang Prosedur Mediasi di Pengadilan.

Riduan Syahrani. Seluk Beluk dan Asas-Asas Hukum Perdata. (Bandung: Alumni, 1985)

Sofyan Hasan. Dasar-Dasar Memahami Hukum Islam di Indonesia. (Surabaya: Usahan Nasional, 1994)

Sudikno Mertokusumo. Hukum Acara Perdata Indonesia. (Yogyakarta: Liberty, 1995

Hak-Hak Istri Dalam Proses Perceraian, http://www.pakarawang.go.id /artikel/baca/21, diakses pada tanggal 9 Desember 2016.

Istri Gugat Cerai Dominasi Kasus Pengadilan Agama Bukittinggi. www.replubika.co.id, diakases tanggal 9 Desember 2016.

Kejarlah Nafkah Sampai Ke Pengadilan, www.hukumonline.com, diakses pada tanggal 9 Desember 2016

UU No. 1 Tahun 1974 tentang Perkawinan.

UUD NRI Tahun 1945 Pasal 1 Ayat (3) yang menyatakan: Negara Indonesia adalah negara hukum. 